\title{
Eradication of Helicobacter pylori: therapies and clinical implications
}

\author{
Humphrey J. O'Connor \\ General Hospital, Tullamore, County Offaly, Eire
}

\begin{abstract}
Summary: This review presents a critical evaluation of the role of Helicobacter pylori eradication in the management of peptic ulcer disease and non-ulcer dyspepsia. On current evidence, $\boldsymbol{H}$. pylori eradication therapy seems likely to emerge as the most rational and cost-efiective treatment for duodenal ulcer. The role of $\boldsymbol{H}$. pylori eradication in the treatment of gastric ulcer and non-ulcer dyspepsia is unclear and requires further study. The emerging problem of antibiotic resistance in $\mathrm{H}$. pylori is of major clinical importance and a prime cause of treatment failure. There is increasing evidence of a link between $H$. pylori and gastric cancer but it is premature to recommend large-scale eradication of $H$. pylori as a valid strategy for the primary prevention of gastric cancer. The search continues for the ideal $\boldsymbol{H}$. pylori eradication regimen.
\end{abstract}

\section{Introduction}

Since Warren and Marshall ${ }^{1}$ first described the presence of Campylobacter-like organisms (now Helicobacter pylori $i^{2}$ ) in the human stomach, there has been phenomenal growth, which continues apace, in the volume of research literature on this microorganism. Several excellent general reviews on $H$. pylori are now available. ${ }^{3-6}$ Much recent interest, however, has centered on eradication of infection and this review specifically focuses on the therapies available and the clinical implications of eradication of $H$. pylori in peptic ulcer disease and non-ulcer dyspepsia. The evidence linking $H$. pylori and gastric cancer is also evaluated and the possible future role of $H$. pylori eradication in the primary prevention of gastric cancer is commented on.

\section{Duodenal ulcer}

The early observations by the Perth group ${ }^{7}$ that over $95 \%$ of duodenal ulcer patients had $H$. pylori infection and that the ulcer-healing agent colloidal bismuth subcitrate (CBS) was helicobactericidal provoked detailed re-evaluation of the role of bismuth and antibiotics in the treatment of duodenal ulcer disease. The fact that CBS was as effective as cimetidine or ranitidine in healing ulcers and somehow prevented ulcer relapse was already

Correspondence: H.J. O'Connor, M.D., F.R.C.P.I. Accepted: 5 March 1992 well known though ill understood. ${ }^{8-10}$ Further interest was generated by early reports that furazolidone $^{11}$ and metronidazole, ${ }^{12}$ both active against $H$. pylori, were as effective as $\mathrm{H}_{2}$ blockers in healing duodenal ulcer.

Our understanding of both the pathogenic role of $\mathrm{H}$. pylori and of the mode of action of bismuth in duodenal ulcer took a major step forward with publication of the landmark study of Coghlan et $a .^{13}$ In this single-blind trial, 66 patients were randomized to 6 weeks therapy with either CBS (DeNol) liquid $(120 \mathrm{mg}$ four times a day) or cimetidine ( $400 \mathrm{mg}$ twice a day). Healing rates were similar in the two groups but over a 12 month follow-up period, ulcer relapse occurred in $79 \%$ of patients who remained $H$. pylori-positive after treatment compared with only $27 \%$ of those rendered $H$. pylori-negative. Histological gastritis was universal in the $H$. pylori-positive group but absent in the $H$. pylori-negative group. Only posttreatment $\boldsymbol{H}$. pylori status was a significant predictor of ulcer relapse. In a reply to Coghlan's paper, Bianchi Porro and Lazzaroni ${ }^{14}$ reported that they were unable to demonstrate $H$. pylori as a risk factor for duodenal ulcer recurrence but this was a small uncontrolled study with only a 6 month follow-up period during which one patient group continued on maintenance $\mathrm{H}_{2}$ blocker therapy that may have prevented ulcer relapse in $H$. pylori-positive patients. Furthermore, several subsequent studies ${ }^{15-20}$ have confirmed Coghlan's findings (Table I).

In the study by Marshall et al. ${ }^{16} 100 \mathrm{H}$. pylori- 
Table I H. pylori eradication and duodenal ulcer relapse

\begin{tabular}{|c|c|c|c|c|c|}
\hline \multirow[b]{2}{*}{ Study } & \multirow[b]{2}{*}{ Treatment } & \multirow{2}{*}{$\begin{array}{l}\text { Patients } \\
\mathrm{n}\end{array}$} & \multirow{2}{*}{$\begin{array}{l}\text { Follow-up } \\
\text { duration } \\
\text { (months) }\end{array}$} & \multicolumn{2}{|c|}{ Ulcer relapse } \\
\hline & & & & $H P+v e$ & $H P-v e$ \\
\hline Coghlan et al. $(1987)^{13 *}$ & CBS vs CIM & 40 & 12 & $19 / 25(79 \%)$ & $4 / 15(27 \%)$ \\
\hline Lambert et al. $(1987)^{15}$ & CBS & 20 & 6 & $8 / 8(100 \%)$ & NS \\
\hline Marshall et al. $(1988)^{16}$ & $\begin{array}{l}\text { CBS vs CBS + TIN } \\
\text { vs CIM vs CIM + TIN }\end{array}$ & 68 & 12 & $37 / 44(84 \%)$ & $5 / 24(21 \%)$ \\
\hline Smith et al. $(1988)^{17}$ & CBS $v s$ RAN & 44 & 18 & $18 / 22(82 \%)$ & $7 / 22(32 \%)$ \\
\hline Fiocca et al. $(1991)^{19}$ & $\begin{array}{l}\text { CBS vs CBS + AMOX } \\
v s \text { RAN vs RAN + AMOX }\end{array}$ & 144 & 6 & $55 / 114(48 \%)$ & $3 / 30(10 \%)$ \\
\hline Lamouliatte et al. $(1991)^{20}$ & $\begin{array}{l}\mathrm{OM}+\mathrm{AMOX} \\
v s \mathrm{OM}+\mathrm{AMOX}+\mathrm{TIN} \\
v s \mathrm{RAN}+\mathrm{AMOX}+\mathrm{TIN}\end{array}$ & 44 & 12 & $15 / 18(83 \%)$ & $1 / 26 \quad(4 \%)$ \\
\hline
\end{tabular}

*Reference; $\mathrm{AMOX}=$ amoxycillin; $\mathrm{CBS}=$ colloidal bismuth subcitrate; $\mathrm{CIM}=$ cimetidine $; \mathrm{HP}=H$. pylori $\mathrm{NS}=$ not stated; $\mathrm{OM}=$ omeprazole; $\mathrm{RAN}=$ ranitidine; $\mathrm{TIN}=$ tinidazole; $+\mathrm{ve}=$ positive; $-\mathrm{ve}=$ negative .

positive duodenal ulcer patients were randomized to 8 weeks therapy with either cimetidine or CBS tablets with tinidazole or placebo administered concurrently for the first 10 days of treatment. Of the patients who remained $H$. pylori-positive after therapy, only $61 \%$ of ulcers healed and $84 \%$ relapsed over the 12 month follow-up period, whereas $92 \%$ of ulcers healed and only $21 \%$ relapsed in the patients $H$. pylori-negative after therapy. The highest eradication rate was achieved in the group who received dual therapy with CBS and tinidazole. Sex, age, smoking and history of previous ulcer had no significant effect on relapse provided $H$. pylori had been eradicated. It is noteworthy, however, that over $20 \%$ of ulcers relapsed despite $H$. pylori eradication, implying that factors other than $H$. pylori are involved in duodenal ulcer relapse.

Two recent studies ${ }^{21,22}$ have gone further and claimed cure of duodenal ulcer after eradication of $H$. pylori. Both studies recruited $H$. pylori-positive patients with troublesome ulcer disease (breakthrough despite maintenance $\mathrm{H}_{2}$ blocker therapy or frequent relapse) who were openly prescribed triple therapy with CBS, metronidazole and either amoxycillin ${ }^{21}$ or tetracycline. ${ }^{22}$ Ulcer relapse was not seen in $H$. pylori-negative patients in either study including a 4 year follow-up by the Australian group. ${ }^{22}$ Despite these impressive results use of the term 'cure' may be premature, particularly in view of the relapsing nature of ulcer disease, ${ }^{23}$ the relatively short follow-up period, and the potential for reinfection with $H$. pylori. ${ }^{24}$ Both studies again support a dominant role for $H$. pylori in duodenal ulcer recurrence and also suggest that the lower relapse rate seen after CBS therapy ${ }^{8-10}$ predominantly results from the antibacterial action of the drug $^{25}$ rather than its cytoprotective properties ${ }^{26}$ or a 'depot' effect after absorption. ${ }^{27}$

\section{Clinical implications}

\section{Choice of treatment in duodenal ulcer}

Histamine $\mathrm{H}_{2}$ blockers offer safe, rapid symptom relief and healing in duodenal ulcer. ${ }^{28}$ Thein $\overrightarrow{0}$ Achilles heel, however, is ulcer relapse whic $\frac{0}{N}$ occurs in up to $90 \%$ of patients within a year after. discontinuing therapy. ${ }^{29,30}$ On present evidence eradication of $\boldsymbol{H}$. pylori offers a clear opportunity to prevent ulcer relapse and effectively alter the natural history of the disease. Thus, should all duodenal ulcer patients with $H$. pylori infection now receive eradication therapy?

Some gastroenterologists would say 'yes' in view of the chronicity of the disease and the potential for relapse and complications. On the other hand, patients who suffer a mild symptomatic relapse once or twice a year, which is easily controlled by a short course of $\mathbf{H}_{2}$ blocker therapy, seem unlikely to benefit much from $H$. pylori eradication therapy. In contrast, patients who suffer frequent troublesome ulcer relapse and need continuous $\mathrm{H}_{2}$ blocker therapy or are being considered for ulcer surgery should be offered an effective eradication regimen such as CBS $120 \mathrm{mg}$ four times a day for 4 weeks with metronidazole $400 \mathrm{mg}$ and tetracycline 500 $\mathrm{mg}$ both three times a day for the first week of $\mathrm{N}$ therapy. ${ }^{31-33}$ Logan et al..$^{34}$ have recently described $N$ a short one-week regimen consisting of CBS $120 \mathrm{mg}$ and amoxycillin $500 \mathrm{mg}$ both four times a day for 7 days with metronidazole $400 \mathrm{mg}$ five times daily for 3 days which gave an overall eradication rate of $72 \%$, increasing to $93 \%$ in patients with metronidazole-sensitive $H$. pylori. The potential impact of $H$. pylori therapy in the prevention of ulcer haemorrhage and perforation remains to be assessed, though George et al. ${ }^{22}$ 
provide anecdotal evidence of a possible beneficial effect.

\section{Antibiotic resistance}

As clinical experience with $H$. pylori eradication increases, it has become clear that the problem of $H$. pylori antibiotic resistance, and particularly nitroimidazole resistance, is of major importance. The widespread adoption of the nitroimidazoles, and especially metronidazole, in eradication regimens owes much to the early eradication studies of Marshall and colleagues, ${ }^{35}$ and the fact that metronidazole is both bactericidal at low $\mathrm{pH}^{36}$ and present in high concentration in gastric juice. ${ }^{37}$ Ironically, the Perth group also highlighted the problem of antibiotic resistance when tinidazoleresistant $\boldsymbol{H}$. pylori emerged in the course of their duodenal ulcer relapse study ${ }^{16}$ in nearly all patients not receiving concurrent CBS therapy. Goodwin et $a l .{ }^{38}$ subsequently showed that nitroimidazole resistance could be prevented by coadministration of CBS.

More recent studies have shown a strong association between primary nitroimidazole resistance in $H$. pylori and both previous administration of these agents for unrelated reasons ${ }^{39}$ (vaginal infections, amoebiasis, giardiasis, perioperative prophylaxis in uterine and colonic surgery) and ethnic origin. ${ }^{40}$ The rate of primary resistance to metronidazole among native-born Belgians was only $17 \%$ compared with $84 \%$ in adults from Zaire. ${ }^{40}$ It is also clear that routine metronidazolesensitivity testing of $H$. pylori cultured from antral biopsies can predict treatment outcome. Weil et $a l^{41}$ using dual-therapy metronidazole and CBS achieved an $85 \%$ eradication rate in patients with metronidazole-sensitive isolates compared with only $14 \%$ in patients with metronidazole-resistant $H$. pylori. In effect, eradication regimens incorporating nitroimidazoles are unable to eradicate $H$. pylori in cases of primary nitroimidazole resistance, and treatment failure in nitroimidazole-sensitive strains may induce secondary resistance. These data further emphasize that comparisons of treatment schedules for $H$. pylori infection should ideally be done in patient groups where the level of antibiotic resistance is similar. Fears have also been expressed $^{33}$ that indiscriminate use of $H$. pylori therapy might promote the emergence of 'superresistant' bacteria and paradoxically increase the problems of eradication in the future.

Finally, current treatment options for nitroimidazole-resistant $H$. pylori are limited but Logan et $a .^{42}$ have devised a 2 -week eradication regimen consisting of omeprazole $40 \mathrm{mg}$ mane and amoxycillin $500 \mathrm{mg}$ four times a day for 2 weeks, with CBS $120 \mathrm{mg}$ four times a day for days $1-7$, and ciprofloxacin $750 \mathrm{mg}$ twice daily for days $7-14$ which gave an eradication rate of $74 \%$ in patients with known metronidazole-resistant $H$. pylori.

\section{Omeprazole}

Omeprazole is a potent inhibitor of gastric acid secretion which exerts its effect by inactivating the $\mathrm{H}+/ \mathrm{K}+$ ATPase enzyme system in the parietal cell canaliculus after proton-dependent activation of the prodrug. ${ }^{43}$ Omeprazole and other substituted benzimidazoles (pantoprazole and lansoprazole) are active against $H$. pylori in vitro. ${ }^{44,45}$ This finding and early reports that omeprazole was effective in eradicating $H$. pylori in vivo ${ }^{46,47}$ generated considerable interest. More rigorous long-term evaluation, however, has shown that omeprazole per se causes suppression but not eradication of $H$. pylori in vivo. ${ }^{48,49}$ On the premise that omeprazoleinduced hypochlorhydria might prevent acid inactivation of antibiotics used to eradicate $H$. pylori, omeprazole has also been evaluated in dual and triple therapy regimens. For instance, preliminary studies of an amoxycillin-omeprazole regimen ${ }^{50}$ achieved a $67 \%$ eradication rate compared with $85 \%$ for an omeprazole-amoxycillin-tinidazole combination $^{51}$ and $50 \%$ for combination omeprazole-CBS-erythromycin. ${ }^{52}$

\section{Gastric ulcer}

The association between $H$. pylori and peptic ulcer disease is stronger for duodenal than for gastric ulceration, in that virtually all duodenal ulcer patients have $H$. pylori-positive antral gastritis whereas about $30 \%$ of gastric ulcer patients are consistently $H$. pylori-negative. ${ }^{53}$ This finding coupled with the relative rarity of gastric compared with duodenal ulcer may account for the dearth of data on the effects of $H$. pylori eradication in gastric ulcer.

In a study of $43 \mathrm{H}$. pylori-positive gastric ulcer patients randomized to receive 12 weeks treatment with either cimetidine or cimetidine plus cefixime in the last 2 weeks of therapy, Tatsutu et al ${ }^{54}$ found a similar healing rate in the two groups but a significantly lower recurrence rate at 12 weeks after finishing treatment in the dual therapy group; ulcer recurrence was, however, similar in the two groups at 24 weeks. Clearly, further studies of $H$. pylori eradication in gastric ulcer are needed which will incorporate large patient numbers, more effective eradication regimens and longer follow-up.

\section{Socioeconomic impact of $\boldsymbol{H}$. pylori eradication}

The socioeconomic costs of peptic ulcer disease are very high. Firstly, peptic ulcer disease is a common 
condition which affects between 1 and $2 \%$ of adults in Western society annually and carries a lifetime prevalence in the population of about $10 \% .{ }^{55}$ Secondly, peptic ulcer is a chronic disorder, characterized by frequent recurrences which may be complicated by life-threatening bleeding or perforation. The direct costs of peptic ulcer disease include consultations, diagnostic tests, hospitalization and drug therapy, whereas the indirect costs include absenteeism, poor work performance and quality of life and possible death from complications. ${ }^{56}$ Continuous maintenance $\mathrm{H}_{2}$ blocker therapy is cost-effective for peptic ulcer largely by reducing direct medical costs ${ }^{57}$ but entails considerable cumulative expense for the patient over several years.

Though they have not yet been directly compared in a controlled clinical trial, current evidence suggests that effective $H$. pylori eradication therapy gives an ulcer relapse rate at least as low as maintenance $\mathrm{H}_{2}$ blocker therapy. Thus, by minimizing direct and indirect costs without the need for expensive maintenance therapy, it seems likely that $H$. pylori eradication therapy may prove the most cost-effective treatment for peptic ulcer. ${ }^{58}$

\section{Non-ulcer dyspepsia}

The term dyspepsia refers to chronic or recurrent upper abdominal symptoms (pain, discomfort, nausea, flatulence, bloating, heartburn), often related to eating, which raise the possibility of peptic ulcer disease. ${ }^{59}$ On investigation, about a third of patients will be shown to have a peptic ulcer, a third various other diagnoses such as gallstones and irritable bowel syndrome, and the remainder will have no obvious abnormality, i.e. have non-ulcer dyspepsia (NUD). ${ }^{60}$

The pathogenesis of NUD remains unknown with inconclusive evidence for several factors including gastric acid secretion, ${ }^{59}$ abnormal gastro- duodenal motility, ${ }^{61}$ duodenogastric reflux, ${ }^{62,63}$ gastrointestinal peptide hormones, ${ }^{64}$ personality traits, ${ }^{65}$ and stress. ${ }^{66}$ The relationship between $H$. pylori and NUD is controversial. The reported prevalence of $H$. pylori-associated gastritis in NUD ranges from $39 \%{ }^{67}$ to $87 \%{ }^{68}$ but it remains unclear whether $H$. pylori infection per se causes chronic dyspeptic symptoms. ${ }^{7,69-71}$ A typical clinical syndrome for $H$. pylori infection has not been identified, ${ }^{72}$ the infection occurs in healthy asymptomatic individuals, ${ }^{73}$ and voluntary ${ }^{74}$ or inadvertent $^{75}$ ingestion of $H$. pylori causes only a shortlived dyspeptic illness.

Controlled studies of $H$. pylori therapy in NUD have yielded conflicting results (Table II). Of six placebo-controlled trials of bismuth in the treatment of NUD,,$^{67,76-80}$ three ${ }^{67,77,80}$ reported significant clinical improvement associated with clearance of $H$. pylori. In placebo-controlled trials of antibiotics in NUD, Ponderoux et al. ${ }^{81}$ found that amoxycillin improved symptoms associated with clearance of $H$. pylori and resolution of gastritis whereas Patchett et al. ${ }^{82}$ found no correlation between eradication of $H$. pylori and short-term symptomatic improvement. Relatively small study populations coupled with differences in definition of NUD and thus in inclusion/exclusion criteriø may account for some of these disparate resultso and all but one of the studies ${ }^{82}$ assessed clearance rather than eradication. In an interesting one yeat follow-up of the patients studied by Patchett et al..$^{82}$ it is noteworthy that dyspepsia scores in patients with persistent $H$. pylori infection were significantly higher than in patients remaining free of infection, suggesting that eradication of $H$. pylori in NUD may produce beneficial long-term effects. ${ }^{83}$ At present, pending further data, $H$. pylori therapy in NUD should ideally remain within the confines of a controlled clinical trial.

Table II $H$. pylori eradication in non-ulcer dyspepsia

\begin{tabular}{|c|c|c|c|c|c|}
\hline Study & Treatment & $\begin{array}{c}\text { Patients } \\
\mathbf{n}\end{array}$ & $\begin{array}{c}H P+v e \\
\mathrm{n}(\%)\end{array}$ & $\begin{array}{l}\text { Follow-up } \\
\text { duration } \\
\text { (weeks) }\end{array}$ & $\begin{array}{c}\text { Symptomatic improvement } \\
\text { with } H P \\
\text { clearance }\end{array}$ \\
\hline McNulty et al. $(1986)^{76}$ & $\begin{array}{l}\text { BS } v s \text { EE } \\
v s \text { placebo }\end{array}$ & 50 & $50(100)$ & 3 & No \\
\hline Rokkas et al. $(1988)^{67}$ & CBS vs placebo & 52 & 20 (39) & 8 & Yes \\
\hline Loffeld et al. $(1989)^{78}$ & CBS vs placebo & 50 & $50(100)$ & 8 & No \\
\hline Lambert et al. $(1989)^{77}$ & CBS vs placebo & 82 & $50(61)$ & 4 & Yes \\
\hline Kang et al. $(1990)^{79}$ & CBS vs placebo & 51 & 20 (39) & 8 & No \\
\hline Vaira et al. $(1991)^{80}$ & CBS vs placebo & 80 & $80(100)$ & NS & Yes \\
\hline
\end{tabular}

*Reference; $\mathbf{B S}=$ bismuth salicylate; $\mathrm{CBS}=$ colloidal bismuth subcitrate; $\mathrm{EE}=$ erythromycin ethylsuccinate; $\mathrm{HP}=H$. pylori NS = not stated; + ve = positive. 


\section{Gastric cancer}

There is growing evidence of a link between $H$. pylori infection and gastric cancer ${ }^{84}$ Gastric cancer almost always develops on a background of chronic gastritis ${ }^{85}$ and $H$. pylori is now increasingly recognized as the cause of type B chronic gastritis, ${ }^{86}$ the predominantly antral form of chronic gastritis which is by far the commonest form worldwide. ${ }^{87}$ There are close parallels between the epidemiology of $H$. pylori infection and gastric cancer. In areas of high prevalence for both gastric cancer and chronic gastritis, $\boldsymbol{H}$. pylori infection is commonly acquired in childhood ${ }^{88,89}$ whereas this is rare in countries such as North America with a low prevalence of gastric cancer. ${ }^{90}$ There is a strong association between gastric cancer risk and overcrowding in the home during childhood which might act by promoting the transmission of $H$. pylori infection. ${ }^{91}$ The frequency of $H$. pylori infection is increased in subjects from the lower social classes, ${ }^{92,93}$ who are also known to have a significantly higher prevalence of gastric cancer. ${ }^{94}$

Serological studies in rural China have shown a significant geographical correlation between gastric cancer mortality and the prevalence of antibody to $H$. pylori ${ }^{95}$ Furthermore, three recent independent case-control studies ${ }^{96-98}$ found that infection with $H$. pylori was associated with an increased risk of gastric cancer. Parsonnet et al..$^{97}$ found that persons seropositive for $H$. pylori were approximately three times more likely to develop gastric cancer in the ensuing years of follow-up than were control subjects matched for age, sex and race. Nomura et al..$^{98}$ also showed that as the level of antibody to $H$. pylori increased, there was a progressive increase in the risk of gastric cancer.

Vitamin $C$ is both a potent antioxidant and an effective scavenger of nitrite, reducing it to nitric oxide and preventing $\mathrm{N}$-nitroso compound formation in vitro ${ }^{99}$ and in vivo. ${ }^{100} \mathrm{~N}$-nitroso compounds, formed by the interaction of nitrite and nitrosatable substrates, are powerful carcinogens which may well play a key role in the initiation of gastric cancer. ${ }^{101}$ Gastric levels of vitamin $C$ are substantially lower in patients with type B chronic gastritis. ${ }^{102-104}$ Also, gastric secretory studies, ${ }^{102,105}$ including detailed studies in a normal subject who inadvertently contracted $H$. pylori infection, ${ }^{106}$ suggest that vitamin $C$ is secreted by the stomach and that secretory capacity is impaired in the presence of gastritis. Hence, $H$. pylori infection may diminish the antioxidant and nitrite-scavenging capacity of gastric juice, thereby increasing the potential for $\mathrm{N}$-nitroso compound formation in the stomach.

Acid secretion diminishes when type B gastritis extends to involve the body of the stomach. ${ }^{107}$ Resultant hypochlorhydria leads to bacterial over- growth and a rise in gastric juice nitrite due to reduction of salivary and dietary nitrate by nitratereductase active bacteria. ${ }^{108,109}$ This in turn leads to increased levels of $\mathrm{N}$-nitroso compounds in the gastric juice of some hypochlorhydric subjects compared with controls. ${ }^{110}$

Given this setting of enhanced potential for DNA damage, the increased cell turnover and mucosal instability inherent in chronic gastritis, ${ }^{111}$ and the known chronicity of $H$. pylori infection, it is conceivable that a series of mutations could occur causing progressive mucosal dedifferentiation from complete to incomplete intestinal metaplasia ${ }^{112,113}$ and on to gastric dysplasia. Progression to invasive gastric cancer may ultimately hinge on individual susceptibility factors such as gender, ${ }^{114}$ blood group, ${ }^{115}$ oncogenes, ${ }^{116}$ DNA repair capacity, ${ }^{117}$ or cellular concentrations of thiols. ${ }^{118}$

Current strategies for the primary prevention of gastric cancer focus on reducing human exposure to $\mathrm{N}$-nitroso compounds by controlling levels of nitrate in drinking water and foodstuffs. If, however, the $H$. pylori-gastric cancer hypothesis holds true and $H$. pylori is shown to play a pivotal role in the pathogenesis of gastric cancer, eradication of infection could become a prime target for cancer prevention. On present evidence, populations with a high incidence of gastric cancer who acquire $H$. pylori infection early in life would probably benefit most from screening for infection and subsequent eradication.

\section{Conclusions}

In the 10 years since its rediscovery, $H$. pylori has established itself as a major contributory factor in the aetiology of peptic ulcer disease ${ }^{3-6,119}$ Eradication of $H$. pylori in duodenal ulcer dramatically alters the relapsing nature of the disease and an effective helicobactericidal regimen now seems the most rational and cost-effective treatment. The role of $H$. pylori eradication in the treatment of both gastric ulcer and NUD is unclear and requires further evaluation. Systematic follow-up of patients given $H$. pylori eradication therapy is essential to provide accurate long-term data on the critical issues of reinfection and peptic ulcer recurrence. The emerging problem of antibiotic resistance is of major clinical importance and is both a prime cause of treatment failure and a potent reason why random speculative $H$. pylori therapy should be discouraged. Although the link between $H$. pylori and gastric cancer is supported by attractive circumstantial evidence, it is still premature to recommend a large-scale population-based $H$. pylori eradication programme as a valid strategy for the primary prevention of gastric cancer.

The search continues for the ideal $H$. pylori 
eradication regimen. Current multi-drug regimens do not offer $100 \%$ eradication, are ineffective against antibiotic-resistant $H$. pylori, discourage patient compliance, may encourage secondary antibiotic resistance and are potentially toxic. The ideal therapeutic agent should have a bactericidal mode of action, including efficacy against quiescent coccoid forms of $H$. pylori, possess both topical and systemic activity, be effective across a wide $\mathrm{pH}$ range, and be well tolerated and cheap. The

\section{References}

1. Warren, J.R. \& Marshall, B. Unidentified curved bacilli on gastric epithelium in active chronic gastritis (letter). Lancet 1983 , i: $1273-1275$.

2. Goodwin, C.S., Armstrong, J.A., Chilvers, T. et al. Transfer of Campylobacter pylori and Campylobacter mustelae to Helicobacter gen. nov. as Helicobacter pylori comb. nov. and Helicobacter mustalae comb. nov., respectively. Int J Syst Bact 1989, 39: 397-405.

3. Blaser, M.J., Gastric Campylobacter-like organisms, gastritis, and peptic ulcer disease. Gastroenterology 1987, 93: $371-383$.

4. Dooley, C.P. \& Cohen, H. The clinical significance of Campylobacter pylori. Ann Intern Med 1988, 108: 70-79.

5. Peterson, W.L. Helicobacter pylori and peptic ulcer disease. $N$ Engl J Med 1991, 324: 1043-1048.

6. Drumm, B. Helicobacter pylori. Arch Dis Child 1990, 65: $1278-1282$.

7. Marshall, B.J. \& Warren, J.R. Unidentified curved bacilli in the stomach of patients with gastritis and peptic ulceration. Lancet 1984, i: $1311-1315$.

8. Martin, D.F., May, S.J., Tweedle, D.E.F., Hollanders, D., Ravenscroft, M.M. \& Miller, J.P. Difference in relapse rates of duodenal ulcer after healing with cimetidine or tripotassium dicitrato bismuthate. Lancet 1981, i: 7-10.

9. Hamilton, I., O'Connor, H.J., Wood, N.C., Bradbury, I. \& Axon, A.T.R. Healing and recurrence of duodenal ulcer after treatment with tripotassium dicitrato-bismuthate tablets or cimetidine. Gut 1986, 27: 106-110.

10. Lee, F.I., Samloff, I.M. \& Hardman, M. Comparison of tripotassium dicitrato bismuthate tablets with ranitidine in healing and relapse of duodenal ulcers. Lancet 1985, i: 1299-1302.

11. Zheng, Z.-T., Wang, Z.-Y., Chu, Y.-X. et al. Double-blind short-term trial of furazolidone in peptic ulcer (letter). Lancet 1985, i: $1048-1049$.

12. Quintero Diaz, M. \& Sotto Escobar, A. Metronidazole versus cimetidine in treatment of gastroduodenal ulcer (letter). Lancet 1986, i: 907

13. Coghlan, J.G., Gilligan, D., Humphries, H. et al. Campylobacter pylori and recurrence of duodenal ulcers - a 12-month follow-up study. Lancet 1987, ii: 1109-1111.

14. Bianchi Porro, G. \& Lazzaroni, M. Campylobacter pylori and ulcer recurrence (letter). Lancet 1988, i: 593.

15. Lambert, J.R., Borromeo, M., Korman, M.G., Hansky, J. \& Eaves, E.R. Effect of colloidal bismuth (De-Nol) on healing and relapse of duodenal ulcers - role of Campylobacter pyloridis (abstract). Gastroenterology 1987, 92 (Suppl): Al489.

16. Marshall, B.J., Goodwin, C.S., Warren, J.R. et al. Prospective double-blind trial of duodenal ulcer relapse after eradication of Campylobacter pylori. Lancet 1988, ii: 1437-1442.

17. Smith, A.C., Price, A.B., Borriello, P. \& Levi, A.J. A comparison of ranitidine and tripotassium dicitratobismuth (TDB) in relapse rates of duodenal ulcer. The role of Campylobacter pylori (CP) (abstract). Gut 1988, 29: A711. worldwide potential benefits of $H$. pylori eradication in the management of gastroduodenal disease will no doubt stimulate continued research in this important area.

\section{Acknowledgement}

My sincere thanks are due to Mrs Moira Waters for $\frac{\bar{c}}{\frac{5}{2}}$ typing the manuscript.

18. Borody, T.J., Cole, P., Noonan, S. et al. Recurrence of duodenal ulcer and Campylobacter pylori infection after eradication. Med J Aust 1989, 151: 431-435.

19. Fiocca, R., Solcia, E. \& Santoro, B. Duodenal ulcer relapse after eradication of Helicobacter pylori (letter). Lancet 1991, $\infty$ i: 1614 .

20. Lamouliatte, H., Bernard, P.H., Boulard, A. et al. Helicobacter pylori eradication prevents duodenal ulcer relapse is (abstract). Gastroenterology 1991, 100 (Suppl): A104.

21. Rauws, E.A.J. \& Tytgat, G.N.J. Cure of duodenal ulcer associated with eradication of Helicobacter pylori. Lancet $\stackrel{\bigcirc}{\triangle}$ 1990, i: 1233-1235.

22. George, L.L., Borody, T.J., Andrews, P. et al. Cure of $\complement$ duodenal ulcer after eradication of Helicobacter pylori. Med $J$ Aust 1990, 153: 145-149.

23. Bardhan, K.D., Cole, D.S., Hawkins, B.W. \& Franks, C.B. $\vec{\bullet}$ Does treatment with cimetidine extended beyond initgi $1 \mathrm{~N}$ healing of duodenal ulcer reduce the subsequent relapse rate? Br Med J 1982, 284: 621-623.

24. Patchett, S., Beattie, S., Leen, E., Keane, C. \& O'Morain, The role of $H$. pylori eradication in the natural history of duodenal ulcer disease (abstract). Rev Esp Enf Digest 1990, 78 (Suppl 1): 121.

25. Goodwin, C.S., Blake, P. \& Blincow, E. The minimum $\stackrel{\unrhd}{\varrho}$ inhibitory and bactericidal concentrations of antibiotics and $\overrightarrow{\vec{D}}$ anti-ulcer agents against Campylobacter pyloridis. J Anti- 윽 microb Chemother 1986, 17: 309-314.

26. Konturek, S.J., Dembinski, A., Warzecha, Z., Bielanski, W., כ, Brzozowski, T. \& Drozdowicz, D. Epidermal growth factor (EGF) in the gastro-protective and ulcer healing actions of colloidal bismuth subcitrate (De-Nol) in rats. Gut 1988, 29: 894-902.

27. Nwokolo, C.U., Gavey, C.J., Smith, J.T.L. \& Pounder, R.E. The absorption of bismuth from oral doses of tripotassium dicitrato bismuthate. Aliment Pharmacol Therap 1989, 3: $\bigcirc$ 29-39.

28. Feldman, M. \& Burton, M.E. Histamine ${ }_{2}$-receptor antagonists: standard therapy for acid-peptic diseases. $N$ Engl $J$ 근 Med 1990, 323: 1672-1680, 1749-1755.

29. Bodemar, G. \& Walan, A. Maintenance treatment of recurrent peptic ulcer by cimetidine. Lancet 1978, i: 403-407.

30. Dronfield, M.W., Batchelor, A.J., Larkworthy, W. \& Langman, M.J.S. Controlled trial of maintenance cimetidine $\mathbb{O}$ treatment in healed duodenal ulcer: short and long-term $N$ effects. Gut 1979, 20: 526-530.

31. O'Riordan, T., Mathai, E., Tobin, E. et al. Adjuvant antibiotic therapy in duodenal ulcers treated with colloidal ${ }_{0}$ bismuth subcitrate. Gut 1990, 31: 999-1002.

32. Tytgat, G.N.J., Axon, A.T.R., Dixon, M.F., Graham, D.Y., $\stackrel{\mathscr{\varrho}}{+}$ Lee, A. \& Marshall, B.J. Helicobacter pylori: causal agent in peptic ulcer disease? Working Party Report of the World Congresses of Gastroenterology. Blackwell Scientific Publications, Melbourne, 1990, pp. 36-45.

33. Axon, A.T.R. Duodenal ulcer: the villain unmasked? $\mathrm{Br} \overparen{\mathbb{D}}$ Med J 1991, 302: 919-921. 
34. Logan, R.P.H., Gummett, P.A., Misiewicz, J.J., Karim, Q.N., Walker, M.M. \& Baron, J.H. One week eradication regimen for Helicobacter pylori. Lancet 1991, i: 1249-1252.

35. Marshall, B.J., Armstrong, J.A., McGechie, D.B. \& Glancy, R.J. Attempt to fulfil Koch's postulates for pyloric campylobacter. Med J Aust 1985, 142: 436-444.

36. Edwards, D.I., Knight, R.C. \& Zahoor, A. DNA damage induced by reductively activated nitroimidazoles - $\mathrm{pH}$ effects. Int J Radiat Oncol Biol Phys 1986, 12: 1207-1209.

37. Hollingworth, J.A., Goldie, J., Silletti, C.F., Li, Y., Richardson, H. \& Hunt, R.H. Gastric secretion of antibiotics used for Campylobacter pyloridis (abstract). Gut 1987, 28 : A1409.

38. Goodwin, C.S., Marshall, B.J., Blincow, E.D., Wilson, D.H., Blackbourn, S. \& Phillips, M. Prevention of nitroimidazole resistance in Campylobacter pylori by coadministration of colloidal bismuth subcitrate: clinical and in vitro studies. J Clin Pathol 1988, 41, 207-210.

39. Becz, M.C.J.M., Janssen, A.J.H.M., Clasener, H.A.L. \& deKoning, R.W. Metronidazole-resistant Helicobacter pylori (letter). Lancet 1990, i: 539-540.

40. Glupczynski, Y., Burette, A., DeKoster, E. et al. Metronidazole resistance in Helicobacter pylori (letter). Lancet 1990, i: 976-977.

41. Weil, J., Bell, G.D., Powell, K. et al. Helicobacter pylori infection treated with a tripotassium dicitrato bismuthate and metronidazole combination. Aliment Pharmacol Therap 1990, 4: 651-657.

42. Logan, R.P.H., Gummett, P.A., Karim, Q.N., Walker, M.M., Baron, J.H. \& Misiewicz, J.J. A treatment regimen for metronidazole-resistant Helicobacter pylori (MRHP) (abstract). Ital J Gastroenterol 1991, 23 (Suppl 2): 110-111.

43. Maton, P.N. Omeprazole. $N$ Engl J Med 1991, 324: 965-975.

44. Suerbaum, S., Leying, H., Hemmerle, B., Klemm, K. \& Opferkuch, W. Antibacterial activity of pantoprozole, omeprazole, and other $(\mathrm{H}+/ \mathrm{K}+)$ ATPase inhibitors against Helicobacter pylori (abstract). Rev Esp Enf Digest 1990, 78 (Suppl 1): 118.

45. Megraud, F., Bouchard, S. \& Lamouliatte, H. Proton pump inhibitors have an antimicrobial activity against Helicobacter pylori (abstract). Gastroenterology 1991, 100 (Suppl): A123.

46. Mainguet, P., Delmee, M. \& Debongnie, J.-C. Omeprazole, Campylobacter pylori, and duodenal ulcer (letter). Lancet 1989, ii: $389-390$.

47. Biasco, G., Miglioli, M., Barbara, L., Corinaldesi, R. \& diFebo, G. Omeprazole, Helicobacter pylori, gastritis, and duodenal ulcer (letter). Lancet 1989, ii: 1403 .

48. Daw, M.A., Deegan, P., Leen, E. \& O'Morain, C. The effect of omeprazole on Helicobacter pylori and associated gastritis. Aliment Pharmacol Therap 1991, 5: 435-439.

49. Weil, J., Bell, G.D., Powell, K. et al. Omeprazole and Helicobacter pylori: temporary suppression rather than true eradication. Aliment Pharmacol Therap 1991, 5: 309-313.

50. Labenz, J., Gyenes, E., Ruhl, G.H. \& Borsch, G. Amoxycillin - omeprazole treatment for eradication of Helicobacter pylori (abstract). Rev Esp Enf Digest 1990, 78 (Suppl I): 96.

51. Lamouliatte, H., Bernard, P.H., Boulard, A., Megraud, F., DeMascarel, A. \& Quinton, A. Controlled study of omeprazole - amoxicillin - tinidazole $v s$ ranitidine - amoxicillin tinidazole in Helicobacter pylori. Associated duodenal ulcers preliminary results (abstract). Rev Esp Enf Digest 1990, 78 (Suppl 1): 101.

52. De Koster, E., Burette, A., Nyst, J.F. et al. HP treatment; bismuth, omeprazole, antibiotics (abstract). Gastroenterology 1991, 100 (Suppl): A52.

53. O'Connor, H.J. \& Axon, A.T.R. Campylobacter pylori, gastric ulceration and the post-operative stomach. In: Rathbone, B.J. \& Heatley, R.V. (eds) Campylobacter pylori and Gastroduodenal Disease. Blackwell Scientific Publications, Oxford, 1989, pp. 125-138.
54. Tatsuta, M., Ishikawa, H., Iishi, H., Okuda, S. \& Yokota, Y. Reduction of gastric ulcer recurrence after suppression of Helicobacter pylori by cefixime. Gut 1990, 31: 973-976.

55. Kurata, J.H. \& Haile, B.M. Epidemiology of peptic ulcer disease. Clin Gastroenterol 1984, 13: 289-307.

56. Jensen, D.M. Health and economic aspects of peptic ulcer disease. Am J Med 1984, 77 (Suppl 5B): 8-14.

57. Fox, N., Morton, R.E. \& Jacobs, J. The cost-effectiveness of maintenance therapy for duodenal ulceration with a $\mathrm{H}_{2}$ antagonist. Aliment Pharmacol Therap 1988, 2: 297-309.

58. Ashton, T. Cost-effectiveness of alternative medications in the treatment of duodenal ulcer. Scand J Gastroenterol 1991, 26: $82-88$.

59. Talley, N.J. \& Phillips, S.F. Non-ulcer dyspepsia: potential causes and pathophysiology. Ann Intern Med 1988, 108: 865-879.

60. Editorial. Non-ulcer dyspepsia. Lancet 1986, i: 1306-1307.

61. Malagelada, J.R. \& Stanghellini, V. Manometric evaluation of functional upper gut symptoms. Gastroenterology 1985 , 88: $1223-1231$

62. Watson, R.G.P. \& Love, A.H.G. Intragastric bile acid concentrations are unrelated to symptoms of flatulent dyspepsia in patients with and without gall bladder disease and postcholecystectomy. Gut 1987, 28: 131-136.

63. Hughes, K., Robertson, D.A.R. \& James, W.B. Duodenogastric reflux in normal and dyspeptic subjects. Clin Radiol 1982, 33: $461-466$.

64. Watson, R.G.P., Shaw, C., Buchanan, K.D. \& Love, A.H.G. Circulating gastrointestinal hormones in patients with flatulent dyspepsia, with and without gallbladder disease. Digestion 1986, 35: 211-216.

65. Talley, N.J., Fung, L.H., Gilligan, I.J., McNeil, D. \& Piper, D.W. Association of anxiety, neuroticism, and depression with dyspepsia of unknown cause. A case control study. Gastroenterology 1986, 90: 886-892.

66. Talley, N.J. \& Piper, D.W. Major life event stress and dyspepsia of unknown cause: a case control study. Gut 1986, 27: $127-134$

67. Rokkas, T., Pursey, C., Uzoechina, E. et al. Non-ulcer dyspepsia and short term De-Nol therapy: a placebo controlled trial with particular reference to the role of Campylobacter pylori. Gut 1988, 29: 1386-1391.

68. Loffeld, R.J.L.F., Stobberingh, E., Flendrig, J.A. \& Arends, J.W. Presence of Helicobacter pylori in patients with nonulcer dyspepsia revealing normal antral histological characteristics. Digestion 1990, 47: 29-34.

69. Timothy, T. \& Schubert, M.D. Non-ulcer dyspepsia symptoms and Helicobacter pylori (abstract). Rev Esp Enf Digest 1990, 78 (Suppl 1): 70.

70. Gasbarrini, G., Pretolani, S., Bonvicini, F. et al. Clinicopathological correlations with Helicobacter pylori presence in dyspeptic patients (abstract). Rev Esp Enf Digest 1990, 78 (Suppl 1): 68.

71. Loffeld, R.J.L.F. \& Adang, R.P.R. Computerised history taking for the assessment of Helicobacter pylori in non-ulcer dyspepsia? A pilot study (abstract). Rev Esp Enf Digest 1990, 78 (Suppl 1): 70-71.

72. Sobala, G.M., Dixon, M.F. \& Axon, A.T.R. Symptomatology of Helicobacter pylori - associated dyspepsia. Eur J Gastroenterol Hepatol 1990, 2: 445-449.

73. Barthel, J.S., Westblom, U., Havey, A.D., Gonzalez, F. \& Everett, E.D. Gastritis and Campylobacter pylori in healthy, asymptomatic volunteers. Arch Intern Med 1988, 148: $1149-1151$

74. Morris, A. \& Nicholson, G. Ingestion of Campylobacter pyloridis causes gastritis and raised fasting gastric pH. Am J Gastroenterol 1987, 82: 192-199.

75. Ramsey, E.J., Carey, K.V., Peterson, W.L. et al. Epidemic gastritis with hypochlorhydria. Gastroenterology 1979, 76: 1449-1457. 
76. McNulty, C.A.M., Gearty, J.C., Crump, B. et al. Campylobacter pyloridis and associated gastritis: investigator blind, placebo controlled trial of bismuth salicylate and erythromycin ethylsuccinate. $\mathrm{Br} \mathrm{Med} J$ 1986, 293: 645-649.

77. Lambert, J.R., Dunn, K., Borromeo, M., Korman, M.G. \& Hansky, J. Campylobacter pylori - a role in non-ulcer dyspepsia? Scand J Gastroenterol 1989, 24 (Suppl 160): 7-13.

78. Loffeld, R.J.L.F., Potters, H.V.J.P., Stobberingh, E., Flendrig, J.A., Van Spreeuwel, J.P. \& Arends, J.W. Campylobacter associated gastritis in patients with non-ulcer dyspepsia: a double blind placebo controlled trial with colloidal bismuth subcitrate. Gut 1989, 30: 1206-1212.

79. Kang, J.Y., Tay, H.H., Wee, A., Guan, R., Math, M.V. \& Yap, I. Effect of colloidal bismuth subcitrate on symptoms and gastric histology in non-ulcer dyspepsia. A double blind placebo controlled study. Gut 1990, 31: 476-480.

80. Vaira, D., Holton, J., Falzon, M. et al. The benefit of treating dyspeptic patients with normal endoscopic appearances (abstract). Rev Esp Enf Digest 1990, 78 (Suppl 1): 106-107.

81. Ponderoux, P., Amoyal, P., Perez, C. et al. Helicobacter pylori and non ulcer dyspepsia. Results of a randomized double blind study amoxicillin vs placebo. Rev Esp Enf Digest 1990, 78 (Suppl 1): 114.

82. Patchett, S., Beattie, S., Leen, E., Keane, C. \& O'Morain, C. Eradicating Helicobacter pylori and symptoms of non-ulcer dyspepsia. Br Med J 1991, 303: 1238-1240.

83. McCarthy, C., Patchett, S., Collins, R., Beattie, S., Keane, C. \& O'Morain, C. Longterm effect of Helicobacter pylori eradication in non-ulcer dyspepsia (abstract). Gastroenterology 1991, 100 (Suppl): A121.

84. O'Connor, H.J. Helicobacter pylori and gastric cancer: a review and hypothesis. Eur J Gastroenterol Hepatol 1992, 4: 103-109.

85. Correa, P. A human model of gastric carcinogenesis. Cancer Res 1988, 48: 3554-3560.

86. Dixon, M.F. Progress in the pathology of gastritis and duodenitis. In: Williams, G.T. (ed) Current Topics in Pathology Vol. 81. Gastrointestinal Pathology. SpringerVerlag, Berlin, 1990, pp. 1-40.

87. Strickland, R.G. \& Mackay, I.R. A reappraisal of the nature and significance of chronic atrophic gastritis. Am J Dig Dis 1972, 18: 426-440.

88. The Gastrointestinal Physiology Working Group. Helicobacter pylori and gastritis in Peruvian patients: relationship to socioeconomic level, age and sex. Am J Gastroenterol 1990, 85: 819-823.

89. Perez-Perez, G.I., Taylor, D.N., Bodhidatta, L. et al. Seroprevalence of Helicobacter pylori infection in Thailand. $J$ Infect Dis 1990, 161: 1237-1241.

90. Drumm, B., Sherman, P., Cutz, E. \& Karmali, M. Association of Campylobacter pylori on the gastric mucosa with antral gastritis in children. $N$ Engl J Med 1987, 316: 1557-1561.

91. Barker, D.J.P., Coggon, D., Osmond, C. \& Wickham, C. Poor housing in childhood and high rates of stomach cancer in England and Wales. Br J Cancer 1990, 61: 575-578.

92. Sitas, F., Forman, D., Yarnell, J.W.G. et al. Helicobacter pylori infection rates in relation to age and social class in a population of Welsh men. Gut 1991, 32: 25-28.

93. Fox, J.G., Correa, P., Taylor, N.S. et al. Campylobacter pylori-associated gastritis and immune response in a population at increased risk of gastric carcinoma. Am J Gastroenterol 1989, 84: 775-781.

94. Coggon, D. \& Acheson, E.D. The geography of cancer of the stomach. Br Med Bull 1984, 40: 335-341.

95. Forman, D., Sitas, F., Newell, D.G. et al. Geographic association of Helicobacter pylori antibody prevalence and gastric cancer mortality in rural China. Int J Cancer 1990, 46: $608-611$.
96. Forman, D., Newell, D.G., Fullerton, F. et al. Association between infection with Helicobacter pylori and risk of gastric cancer: evidence from a prospective investigation. $\mathrm{Br} \mathrm{Med} \mathrm{J}$ 1991, 302: 1302-1305.

97. Parsonnet, J., Friedman, G.D., Vandersteen, D.P. et al. Helicobacter pylori infection and the risk of gastric carcinoma. N Engl J Med 1991, 325: 1127-1131.

98. Nomura, A., Stemmermann, G.N., Chyou, P.-H., Kato, I., Perez-Perez, G.I. \& Blaser, M.J. Helicobacter pylori infection and gastric carcinoma among Japanese Americans in Hawaii. N Engl J Med 1991, 325: 1132-1136.

99. Mirvish, S.S., Wallcave, L., Eagen, M. \& Shubik, P. Ascorbate-nitrite reaction: possible means of blocking the formation of carcinogenic N-nitroso compounds. Science 1972, 177: 65-68.

100. Ohshima, H. \& Bartsch, H. Quantitative estimation of endogenous nitrosation in humans by monitoring $\mathrm{N}$ nitrosoproline excreted in the urine. Cancer Res 1981, 41: 3658-3662.

101. Mirvish, S.S. The etiology of gastric cancer: intragastric nitrosamide formation and other theories. $J$ Natl Cancer Inst 1983, 71: 631-647.

102. O’Connor, H.J., Schorah, C.J., Habibzedah, N., Axon, A.T.R. \& Cockel, R. Vitamin $\mathrm{C}$ in the human stomach: relation to gastric $\mathrm{pH}$, gastroduodenal disease, and possible sources. Gut 1989, 30: 436-442.

103. Rathbone, B.J., Johnson, A.W., Wyatt, J.I., Kelleher, J, Heatley, R.V. \& Losowsky, M.S. Ascorbic acid: a factor concentrated in human gastric juice. Clin Sci 1989, 76: 237-241.

104. Sobala, G.M., Schorah, C.J., Sanderson, M. et al. Ascorbic acid in the human stomach. Gastroenterology 1989, 97: 357-363.

105. Rathbone, B.J., Johnson, A.W., Jones, C., Kelleher, J. \& Heatley, R.V. Gastric juice 'secretion' of ascorbic acif (abstract). Proc Nutr Soc 1986, 45: 69.

106. Sobala, G.M., Crabtree, J.E., Dixon, M.F. et al. Acut Helicobacter pylori infection: clinical features, local and systemic immune response, gastric mucosal histology, and gastric juice ascorbic acid concentrations. Gut 1991, 32: $1415-1418$

107. Siurala, M., Sipponen, P. \& Kekki, M. Campylobacter pylori in a sample of Finnish population: relations to morphology and functions of the gastric mucosa. Gut 1988, 29: 909-915.

108. Leach, S.A. \& Hill, M.J. The effects of the sustained and profound inhibition of gastric acid production on gut flora. Res Clin Forums 1990, 12: 139-151.

109. Ruddell, W.S.J., Bone, E.S., Blendis, L.M. \& Walters, C.L. Gastric juice nitrite: a risk factor for cancer in the hypochlorhydric stomach? Lancet 1976, ii: 1037-1039.

110. Pignatelli, B., Richard, I., Bourgade, M.-C. \& Bartsch, H. An improved method for analysis of total N-nitroso compounds in gastric juice. In: Bartsch, H., O'Neill, I. \& Schulte-Herman, R. (eds) The Relevance of $N$-nitroso Compounds to Human Cancer. IARC Scientific Publication No. 84. International Agency for Research on Cancer, Lyon, 1987, pp. 209-215.

111. Deschner, E.E. \& Lipkin, M. Proliferation and differentiation of gastrointestinal cells in health and disease. In: Lipkin, M. \& Good, R.A. (eds) Gastrointestinal Tract Cancer. Plenum Medical Books, New York, 1978, pp. 3-24.

112. Jass, J.R. Role of intestinal metaplasia in the histogenesis of gastric cancer. J Clin Pathol 1980, 33: 801-810.

113. Craanen, M.E., Dekker, W., Blok, P., Ferwerda, J. \& Tytgat, G.N.J. Intestinal metaplasia and Helicobacter pylori: an endoscopic bioptic study of the gastric antrum Gut 1992, 33: 16-20.

114. Griffith, G.W. The sex ratio in gastric cancer and hypothetical considerations relative to aetiology. Br J Cancer 1968, 22: 163-172. 
115. Billington, B.P. Gastric cancer: relationships between $\mathbf{A B O}$ blood groups, site, and epidemiology. Lancet 1956, ii: 859-862.

116. Yokota, J., Yamamoto, T., Toyoshima, K. et al. Amplification of c-erbB-2 oncogene in human adenocarcinomas in vivo. Lancet 1986, i: 765-767.

117. Domoradzki, J., Pegg, A.E., Dolan, M.E., Maher, V.M. \& McCormick, J.J. Correlation between 06-methylguanineDNA-methyltransferase activity and resistance of human cells to the cytotoxic and mutagenic effect of $\mathrm{N}$-methyl- $\mathrm{N}^{\prime}$ nitro-N-nitrosoguanidine. Carcinogenesis 1984, 5: 1641-1647.
118. Wiestler, O., von Deimling, A., Kobori, O. \& Kleihues, P. Location of $\mathrm{N}$-methyl-N'-nitro-N-nitrosoguanidine-induced gastrointestinal tumours correlates with thiol distribution. Carcinogenesis 1983, 4: 879-883.

119. Dixon, M.F. Helicobacter pylori and peptic ulceration: histopathological aspects. J Gastroenterol Hepatol 1991, 6: 125-130. 